\title{
An Osteometric Study on Humerus
}

\author{
Estudio Osteométrico del Húmero
}

Aydin Kabakci, A. D. ${ }^{1}$; Buyukmumcu, M. ${ }^{1}$; Yilmaz, M. T. ${ }^{1}$; Cicekcibasi, A. E. ${ }^{1}$; Akın, D. ${ }^{1}$ \& Cihan, E. ${ }^{2}$

AYDIN KABAKCI, A. D.; BUYUKMUMCU, M.; YILMAZ, M. T.; CICEKCIBASI, A. E.; AKıN, D. \& CIHAN, E. An osteometric study on humerus bones. Int. J. Morphol., 35(1):219-226, 2017.

SUMMARY: Humerus is the longest and thickest bone of the upper limb. As a long bone, it has two epiphysis and diaphysis. In this study, we aimed to conduct morphometric measurements belonging to human humerus. This study was conducted on 60 humerus (28 right, 32 left) in collections of Necmettin Erbakan University Meram Medicine Faculty Anatomy Laboratory. Digital calipers, osteometric board and precision scales for humerus bone measurements were used. Measurements were classified as measurements of diaphysis and proximal and distal epiphysis of humerus. Each bone weight was determined. Also nutrient foramen number and localization was determined. In this study, it was determined that mean right humerus length $30.41 \pm 1.73 \mathrm{~mm}$, mean left humerus length $30.04 \pm 2.39$ $\mathrm{mm}$. It was identified that mean right humerus weight was $115.05 \pm 28.06 \mathrm{~g}$, mean left humerus weigh twas $111.63 \pm 33.34 \mathrm{~g}$. In 9 humerus (15\%), supratrochlear foramen has been observed. 6 of these were oval and 3 of them were round. Nutrient foramen has not been observed in two humerus $(3.3 \%)$. Also, medium and weak correlation was identified between many parameters. We believe that the obtained data from this study may be qualities of reference for sex determination from humerus.

KEY WORDS: Humerus; Morphometry, Osteometry.

\section{INTRODUCTION}

Humerus is the longest and thickest bone of the upper extremity and it forms the skeleton of the arm, and connects the shoulder and elbow joints to each other. Besides, it is very important for forensic and anthropological studies (Somesh et al., 2011; Desai \& Shaik, 2012).

In morphometric analyses, it is very important to use well-preserved bones of the human body in terms of anthropological data. Besides the bone structure of the pelvis and cranium, humerus, tibia, femur, sternum, ulna, talus, calcaneus, radius bones are also used in anthropological studies. As a result of the bone deformities formed due to chemical and mechanical factors, the use of durable bones such as humerus has become very common for the sex determination. Therefore, humerus has been frequently used by researchers in forensic and anthropological studies (Bokariya et al., 2011; Tellioglu \& Karakas, 2013). In line with this data, the aim of our study is to perform morphological measurements of humerus segments.

\section{MATERIAL AND METHOD}

Our study was performed with 60 humerus (32 left and 28 right humerus) obtained from the bone collection of Necmettin Erbakan University, Meram Medical University, Anatomy Laboratory. The permissions were obtained from Necmettin Erbakan University, Pharmaceuticals and NonMedical Devices Research Ethics Board (2014/84). Digital calipers, measuring tape, osteometric board and precision scales were used in humerus measurements. Measurements of humerus were divided into three groups such as measurements of proximal epiphysis, diaphysis and distal epiphysis of humerus. Weights of each bone were measured by using precision scale. Furthermore, the number and the localization of foramen nutricium of the bones were also determined.

\section{Measurements of proximal epiphysis of humerus:}

MHL (Maximum humerus length): The distance between the highest point of the humeral head and the lowest point of the trochlea (Fig. 2).

\footnotetext{
${ }^{1}$ Department of Anatomy, Meram Faculty of Medicine, University of Necmettin Erbakan, Konya, Turkey.

${ }^{2}$ Deha Special Education and Rehabilitation Center, Konya, Turkey.
} 


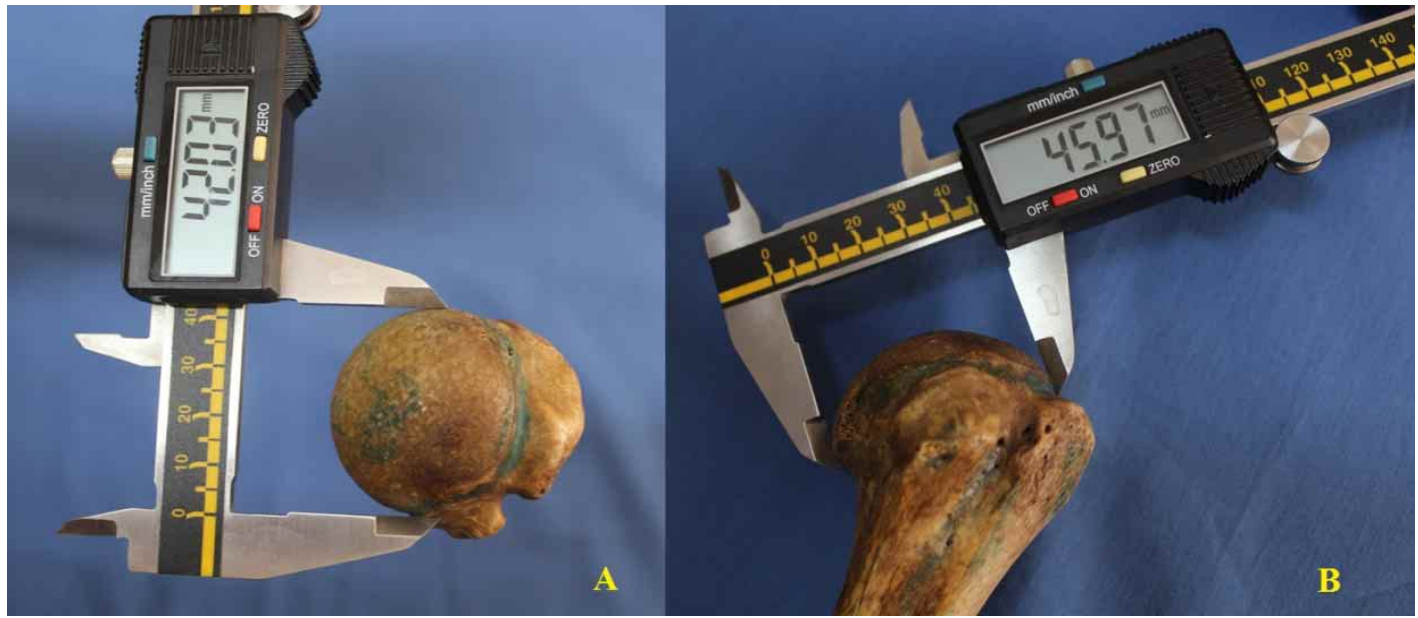

Fig. 1. A:TDHH: Transverse diameter measurement of humeral head and B: VDHH: Vertical diameter measurement of humeral head with digital caliper.

TDHH (Transverse diameter of humeral head): The diameter of the humerus head in the antero-posterior direction (Fig. 1).

VDHH (Vertical diameter of humeral head): The diameter of the bone in the lateral-medial direction (Fig. 1).

CSN(Circumference of surgical neck): The circumference located in the lower point of the humeral head.

BGL-BGW-BGD (Bicipital groove length, width ve depth) (Fig. 2),
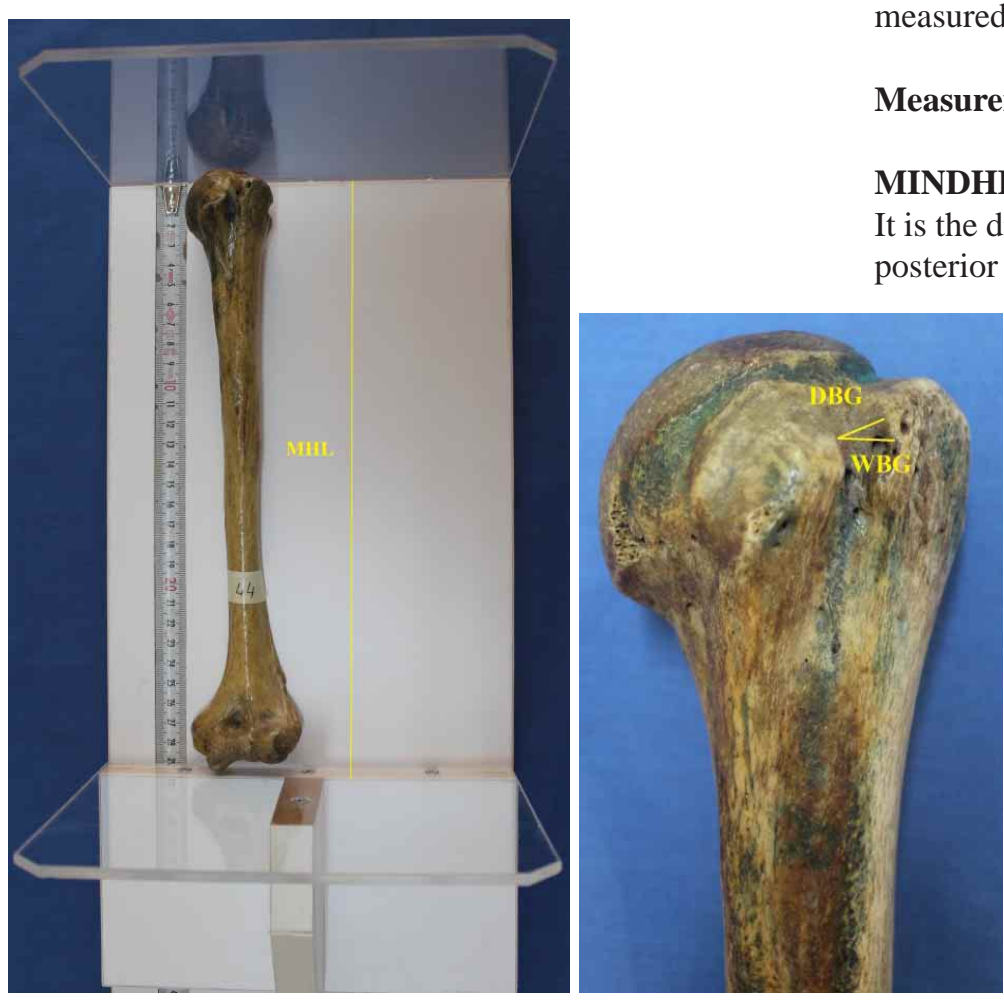

Fig. 2. A. MHL: Maximum humeral length measurement wit osteometric board, B. DBG-WBG: Bicipital groove depth and width with digital caliper
HH-GT: The distance between the highest point of the humeral head and the highest point of the greater tubercule. HH-CSN: The distance between the humeral head and the circumference of surgical neck.

Minimum diameter of humerus diaphysis (MINDHB), and maximum diameter of humerus diaphysis (MAXDHB) were measured by using digital caliper whereas the circumference length of humerus diaphysis (CLHB) was measured by using the measuring tape.

\section{Measurements of the humerus diaphysis:}

MINDHB (Minimum diameter of humerus diaphysis): It is the diameter of the diaphysis of the bone in the anteroposterior direction (Fig. 3).

MAXDHB (Maximum diameter of humerus diaphysis): It is the diameter of the diaphysis of the bone in the medio-lateral direction (Fig. 3).

CLHB (Circumference length of humerus diaphysis)

\section{Measurements of distal epiphysis of humerus:}

LCH-WCH: Length of the capitulum - Width of the capitulum.

LTH-WTH: Length of the trochlea - Width of the trochlea.

LCF-WCF-DCF: Length, width and depth of the coronoid fossa.

LRF-WRF-DRF: Length, width and depth of the radial fossa. 


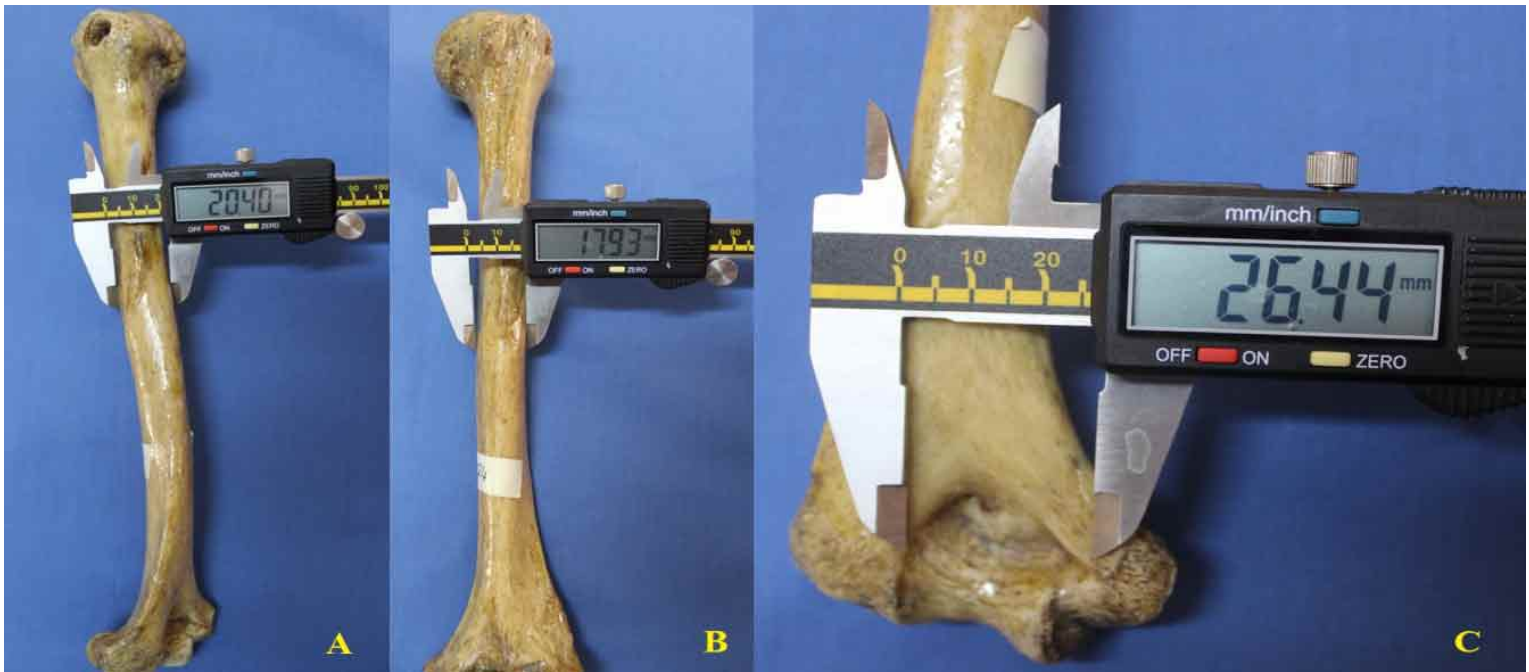

Fig. 3. A: MINDHB:Minimum diameter measurement of humerus diaphysis, B: MAXDHB: Maximum diameter measurement of humerus diaphysis and C: WOF: Width measurement of olecranon fossa with digital caliper

LOF-WOF-DOF: Length, width and depth of the olecranon fossa. (Fig. 3).

POF-DTH: The distance between the proximal point of the olecranon fossa and distal point of the trochlea.

LE-ME: The distance between lateral epicondyle and medial epicondyle.

Maximum humeral length (MHL): The distance between the highest point of the humeral head and the lowest point of the trochlea was measured by using osteometric board whereas the dry weight of the bone was measured by using precision scale (Fig. 4). The number of nutrient foramen was determined by considering the proximal and distal margins of the bone. Furthermore, the number of supratrochlear foramen(SFT) and the vertical and transverse diameters of these holes were also measured. The obtained data were evaluated by using SPSS 21.0 (Statistical Package for Social Sciences). Data were analyzed by both descriptive (mean value, standard deviation, maximum and minimum values, percentages) and quantitative statistical methods. Results were evaluated statistically in $\% 95$ confidence interval and differences were accepted significant if $p<0.01$.

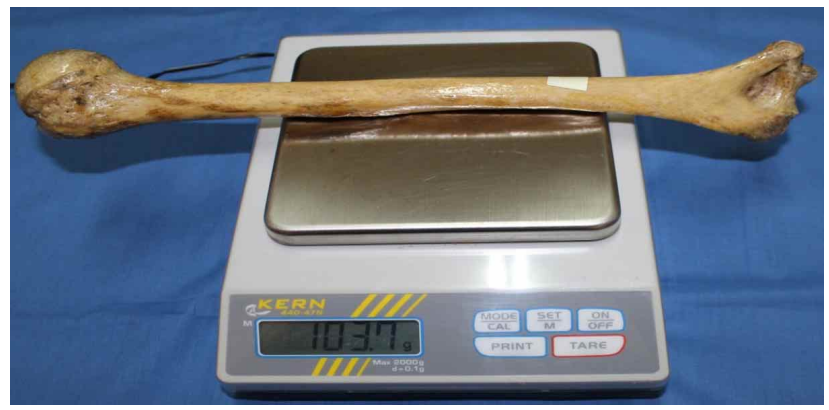

Fig. 4. Weight measurement of humerus with precision scale

\section{RESULTS}

In this study, morphometric measurements were classified into three groups such as proximal epiphysis, humerus diaphysis and distal epiphysis of humerus. Mean, minimum, maximum and standard deviation values of all parameters were determined (Table I). According to morphometric measurements of bones, it was determined that mean of the right humerus length was $304.1 \pm 17.3 \mathrm{~mm}$ and the mean of the left humerus length was $300.4 \pm 23.9 \mathrm{~mm}$. The mean weight of the right humerus was $115.05 \pm 28.06 \mathrm{~g}$ and the mean weight of the left humerus was111.63 $\pm 33.34 \mathrm{~g}$. Supratrochlear foramen was observed in the distal epiphysis of 9 humerus (15\%), and 6 of them $(66.6 \%)$ were oval appearance and 3 of them (33.3\%) had circular shape. It was detected that the mean right transverse diameter of supratrochlear foramen (TDSFT) was $5.23 \pm 3.74$ and the mean right vertical diameter of supratrochlear foramen (VDSFT) was $3.91 \pm 1.91 \mathrm{~mm}$ and $4.80 \pm 2.65 \mathrm{~mm}, 4.21 \pm 1.29 \mathrm{~mm}$ for the left side respectively. Besides, in our study, nutrient foramen was also examined and it was detected that there was one nutrient foramen in 52 humerus ( $86.6 \%$ ), and there were two nutrient foramen in 6 humerus $(10 \%)$. There was no nutrient foramen in two humerus $(3.3 \%)$. Furthermore, there was a weak and moderate relationship between various parameters which were measured in our study (Tables II, III).

\section{DISCUSSION}

In anatomy, paleoanthropology and forensic medicine studies, various bones are frequently used for the sex 
Table I. Mean values, standard deviations and minumum-maximum values of parameters belonging to humerus (mm). (Parameters related to MHL and GSN are centimeter, other parameters are milimeter).

\begin{tabular}{|c|c|c|c|c|c|c|c|c|}
\hline \multirow[b]{2}{*}{ Parameters } & \multicolumn{4}{|c|}{ Right Humerus } & \multicolumn{4}{|c|}{ Left Humerus } \\
\hline & $\mathbf{N}$ & Min. & Max. & Mean \pm SD & $\mathbf{N}$ & Min. & Max. & Mean \pm SD \\
\hline MHL & 26 & 27.50 & 34.20 & $30.41 \pm 1.73$ & 31 & 26.30 & 34.40 & $30.04 \pm 2.40$ \\
\hline TDHH & 24 & 34.15 & 44.47 & $38.29 \pm 3.04$ & 30 & 32.27 & 45.68 & $38.66 \pm 3.92$ \\
\hline VDHH & 24 & 35.70 & 49.33 & $42.41 \pm 3.25$ & 30 & 35.49 & 51.74 & $42.94 \pm 4.01$ \\
\hline GSN & 26 & 7.30 & 10.90 & $8.69 \pm 0.99$ & 31 & 7.20 & 10.60 & $9.32 \pm 0.85$ \\
\hline LBG & 26 & 58.82 & 87.09 & $75.59 \pm 6.05$ & 31 & 65.65 & 96.24 & $77.20 \pm 6.83$ \\
\hline WBG & 26 & 6.12 & 10.42 & $8.06 \pm 1.16$ & 31 & 6.53 & 10.25 & $8.15 \pm 0.92$ \\
\hline DBG & 26 & 2.17 & 7.24 & $4.89 \pm 1.38$ & 31 & 2.20 & 6.25 & $4.48 \pm 0.99$ \\
\hline HH-GT & 24 & 3.44 & 8.77 & $6.39 \pm 1.44$ & 29 & 2.62 & 8.97 & $5.83 \pm 1.72$ \\
\hline HH-GSN & 26 & 27.7 & 40.05 & $33.08 \pm 3.30$ & 31 & 20.96 & 38.68 & $32.50 \pm 3.40$ \\
\hline M_NDHB & 28 & 17.20 & 25.14 & $20.63 \pm 2.15$ & 32 & 15.29 & 23.70 & $19.67 \pm 2.30$ \\
\hline MĀXDHB & 28 & 14.44 & 24.28 & $20.36 \pm 2.35$ & 32 & 18.11 & 25.02 & $20.59 \pm 1.98$ \\
\hline CLHB & 28 & 5.70 & 7.40 & $6.58 \pm 0.47$ & 32 & 6.10 & 8.20 & $6.85 \pm 0.57$ \\
\hline LCH & 28 & 15.81 & 22.83 & $18.32 \pm 1.60$ & 31 & 13.76 & 20.42 & $17.34 \pm 1.84$ \\
\hline WCH & 28 & 14.13 & 18.68 & $15.84 \pm 1.21$ & 31 & 13.95 & 20.45 & $17.12 \pm 1.84$ \\
\hline LTH & 28 & 17.02 & 25.10 & $21.13 \pm 1.92$ & 31 & 16.45 & 25.45 & $20.71 \pm 2.04$ \\
\hline WTH & 28 & 14.78 & 22.53 & $17.71 \pm 2.34$ & 31 & 9.08 & 20.60 & $15.88 \pm 2.38$ \\
\hline LCF & 28 & 6.48 & 13.66 & $11.24 \pm 1.59$ & 32 & 4.41 & 50.93 & $12.54 \pm 7.66$ \\
\hline WCF & 28 & 10.09 & 16.18 & $12.95 \pm 1.73$ & 32 & 6.05 & 15.64 & $12.42 \pm 2.07$ \\
\hline DCF & 28 & 4.99 & 9.35 & $7.44 \pm 1.14$ & 32 & 3.90 & 10.37 & $6.82 \pm 1.35$ \\
\hline LRF & 28 & 6.90 & 10.55 & $8.52 \pm 1.23$ & 32 & 5.05 & 10.14 & $8.03 \pm 1.43$ \\
\hline WRF & 28 & 9.78 & 15.03 & $12.82 \pm 1.79$ & 32 & 8.47 & 16.38 & $10.90 \pm 1.89$ \\
\hline DRF & 28 & 2.17 & 7.26 & $3.41 \pm 1.10$ & 32 & 1.46 & 6.47 & $3.34 \pm 1.01$ \\
\hline LOF & 28 & 16.73 & 23.00 & $19.10 \pm 1.45$ & 32 & 16.18 & 23.08 & $19.46 \pm 1.94$ \\
\hline WOF & 28 & 20.14 & 30.71 & $24.72 \pm 2.31$ & 32 & 20.71 & 29.82 & $25.16 \pm 2.45$ \\
\hline DOF & 28 & 9.82 & 16.74 & $13.41 \pm 1.78$ & 32 & 12.05 & 18.02 & $14.60 \pm 1.44$ \\
\hline POF-DTH & 28 & 29.82 & 38.94 & $33.81 \pm 2.70$ & 32 & 28.52 & 42.06 & $35.69 \pm 3.13$ \\
\hline LE-ME & 26 & 49.42 & 69.37 & $58.21 \pm 4.58$ & 31 & 46.30 & 64.44 & $56.36 \pm 5.01$ \\
\hline ME-TH & 26 & 19.50 & 29.84 & $24.62 \pm 2.41$ & 31 & 20.28 & 32.42 & $26.17 \pm 3.23$ \\
\hline VDSTF & 3 & 2.42 & 6.07 & $3.91 \pm 1.91$ & 6 & 2.85 & 6.31 & $4.21 \pm 1.29$ \\
\hline TDSFT & 3 & 2.11 & 9.40 & $5.23 \pm 3.74$ & 6 & 2.54 & 9.58 & $4.80 \pm 2.65$ \\
\hline WH & 23 & 59.78 & 169.03 & $115.05 \pm 28.06$ & 26 & 47.20 & 172.78 & $111.63 \pm 33.34$ \\
\hline
\end{tabular}

determination. Sex determination can be estimated (almost $100 \%$ reliability) by using primarily pelvis and secondarily skull skeleton bones. Particularly, femur and humerus which are resistant to chemical and mechanical factors, are frequently used in morphometric measurements. Even though individuals in society have similar anatomical structures, there are various differences between female and male individuals. When the sex determination is performed from the skeleton, all morphological characteristics which show the gender difference are examined. These features can be frontal eminence, occipital bone, and other skull bones, features of the face, toot and mandible, the strength and massiveness of long bones, and the general structure of pelvic bone. Furthermore, it is also very important to obtain morphometric values by considering the size differences of various bones in male and female skeletons (Somesh et al.; Desai \& Shaik; Tellioglu \& Karakas; Harun, 2008). In our study, morphometric features of humerus were identified in order to provide a reference study to other studies which aim to perform sex determination by using humerus.
Desai et al. (2014) stated that anatomical data are very crucial in order to optimize the shoulder implants. Besides, they also emphasized that there were no sufficient data on metric values related to bone anatomical structure of the distal humeral hemiarthroplasty. Therefore, they aimed to create a data bank for the implant design by performing morphometric measurements of $\mathrm{CT}$ images of distal epiphysis. As a conclusion, they determined that $\mathrm{WCH}, \mathrm{LCH}$, WTH and LTH were respectively $17,2 \pm 2 \mathrm{~mm}, 23 \pm 2 \mathrm{~mm}$, $22 \pm 3 \mathrm{~mm}$, and $18 \pm 2 \mathrm{~mm}$. Furthermore, they showed that there was a significant relationship between $\mathrm{LCH}-\mathrm{WCH}$ $(\mathrm{r}=0.772)$, WTH-WCH ( $\mathrm{r}=0.676)$, and WTH-LTH $(\mathrm{r}=0.454)$. There was a significant difference between WCH and LCH and capitulum had an ellipsoid appearance instead of spherical appearance. In our study, WCH, LCH, WTH and LTH were found in right-left humerus significantly as $15.84 \pm 1.21-17.12 \pm 1.84,18.32 \pm 1.60-17.34 \pm 1.84$, $17.71 \pm 2.34-15.88 \pm 2.38,21.13 \pm 1.92-20.71 \pm 2.04 \mathrm{~mm}$. Furthermore, the association between LCH-WCH and WTH- 
AYDIN KABAKCI, A. D.; BUYUKMUMCU, M.; YILMAZ, M. T.; CICEKCIBASI, A. E.; AKıN, D. \& CIHAN, E. an osteometric study on humerus bones. Int. J. Morphol., 35(1):219-226, 2017.

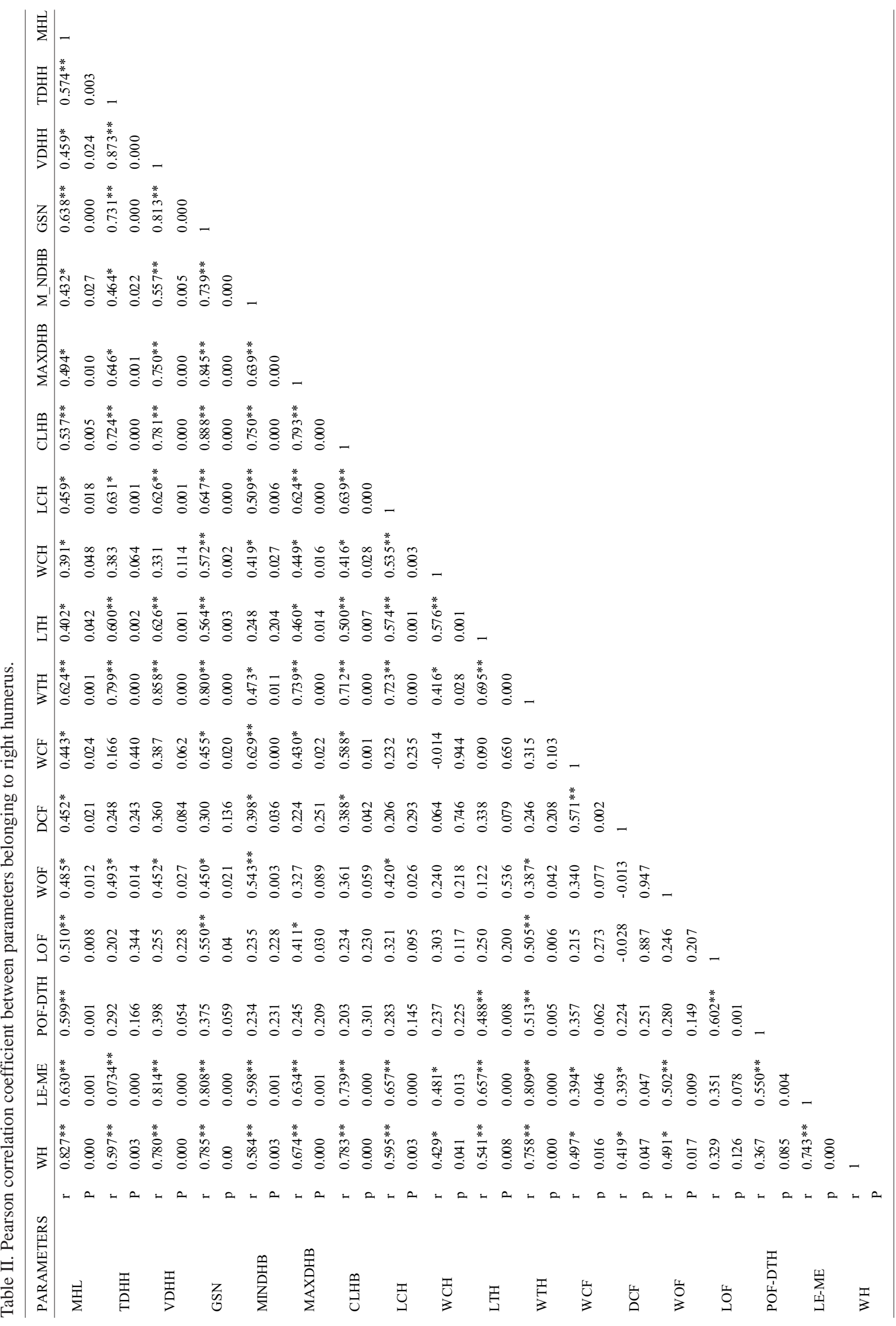


AYDIN KABAKCI, A. D.; BUYUKMUMCU, M.; YILMAZ, M. T.; CICEKCIBASI, A. E.; AKıN, D. \& CIHAN, E. an osteometric study on humerus bones. Int. J. Morphol., 35(1):219-226, 2017.

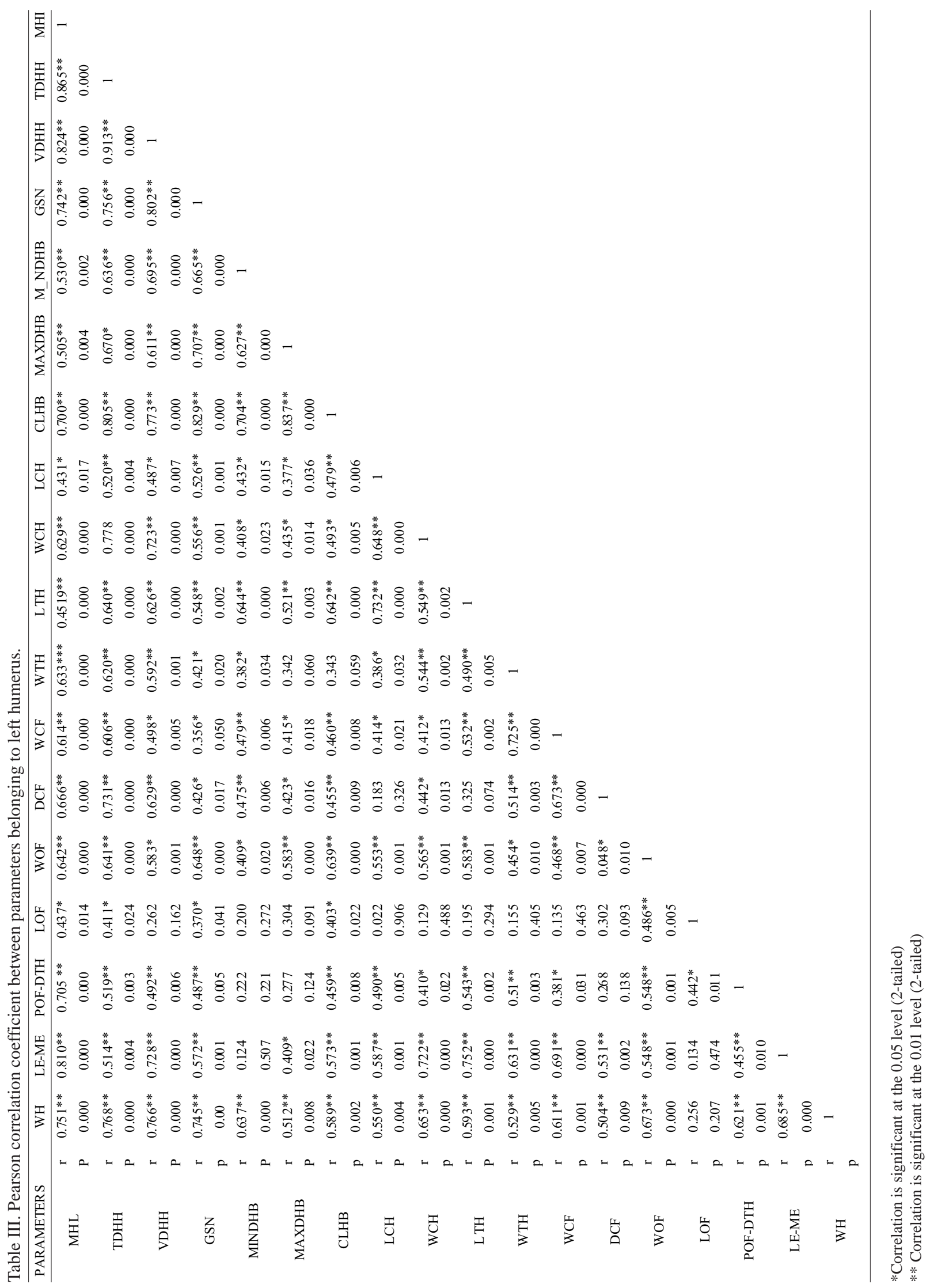


WCH in the right and left humerus was lower compared to the findings of Desai et al. and higher compared to the association between WTH-LTH (Tables I, II, III).

Salles et al. (2009) performed a study with 40 dry adult humerus and they examined the relationship between maximum humerus length and various parameters. They found that there was a significant association between the right maximum humerus length and LE-ME ( $\mathrm{r}=0.69)$, LTH $(\mathrm{r}=0.83)$, TDHH $(r=0.77)$ and VDHH $(r=0.77)(p<0.01)$. Besides, the relationship between the maximum left humerus length and LE-ME, LTH, TDHH and VDHH were determined respectively as $r=0.63, r=0.74, r=0.65, r=0.57$. In our study, the relationship between MHL and LE-ME, LTH, TDHH and VDHH was different than the relationship found in the study of Salles et al., and the length was higher in the left humerus compared to the right humerus (Tables II, III).

In literature, maximum humerus length (MHL) has been determined in various studies. Particularly, it has been specified that the length of the total humerus gives important data about the characteristic features of the population in forensic and anthropological cases (Table IV). In this study, it was determined that mean MHL was $304,1 \pm 17,3 \mathrm{~mm}$ and $300,4 \pm 23,9 \mathrm{~mm}$ respectively on the right and left side of the

Table IV. Maximum humeral lenght (mm).

\begin{tabular}{lcc}
\hline & \multicolumn{2}{c}{ MHL } \\
\hline Researchers & Right & Left \\
\hline Akman et al. $(2006)$ & $307.1 \pm 20.8$ & $304.8 \pm 20.8$ \\
Bokariya et al. $(2011)$ & $312.9 \pm 1.74$ & $307.0 \pm 1.27$ \\
Niraj et al. (2014) & $308.5 \pm 19.16$ & $307.2 \pm 16.13$ \\
Somesh et al. $(2011)$ & $299.6 \pm 22.5$ & $309.6 \pm 20.6$ \\
Desai \& Shaik (2012) & $292.3 \pm 22.9$ & $289.45 \pm 21.8$ \\
Salles et al. (2009) & $313 \pm 23$ & $305 \pm 16$ \\
Latimer \& Lowrance (1965) & $303 \pm 17.71$ & $300.85 \pm 18.3 \xi$ \\
Udhaya et al. $(2011)$ & $302.8 \pm 24.4$ & $299.9 \pm 20.1$ \\
Our study & $304.1 \pm 17.3$ & $300.4 \pm 23.9$ \\
\hline
\end{tabular}

Table V. Prevalance of SFT (\%).

\begin{tabular}{lllc}
\hline Researchers & Population & Samples & Prevalence of SFT (\%) \\
\hline Öztürk et al. $(2000)$ & Egyptians & 114 dired humeri & 7.90 \\
Çimen et al. $(2003)$ & Turks & 114 dired humeri & 12.05 \\
Singhal \& Rao $(2007)$ & South Indians & 150 dired humeri & 28 \\
Nayak et al. $(2009)$ & Indians & 384 dired humeri & 34,3 \\
Li et al. (2015) & Chinese & 262 dired humeri & 10.3 \\
Kaur \& Zorasingh (2013) & Indians & 80 dired humeri & 27.5 \\
Erdo_mu_et al. $(16)$ & Turks & 166 dired humeri & 10.8 \\
Ndou et al. (2013) & South africans & 1076 dired humeri & 32.5 \\
Diwan et al. $(2013)$ & North Indians & 1776 dired humeri & 24.1 \\
Patel et al. (2013) & Indians & 565 dired humeri & 23.5 \\
Sunday et al. $(2014)$ & Nigerians & 65 dired humeri & 27.7 \\
Kumarasamy et al. (2011) & Indians & 214 dired humeri & 31.3 \\
Our study $(2016)$ & Turks & 60 dired humeri & 15 \\
\hline
\end{tabular}

diaphysis. Conclusively, it was found that mean MHL values of our study were compatible with findings of Latimer \& Lowrance (1965), Akman et al. (2006); Udhaya et al. (2011) and Niraj et al. (2014); they were lower compared to findings of Bokariya et al., Salles et al.; and higher compared to findings of Somesh et al., Desai \& Shaik and Desai et al.

Olecranon fractures have $10 \%$ incidence among all extremity lesions. Lesions can occur due to the direct or indirect trauma and particularly due to the forcing excessive extension of the elbow joint. Therefore, anatomical metric values of olecranon can be reference to orthopedic surgeons about fracture reconstruction and the design of various implants. Desai \& Shaik determined that the distance between lengths of proximal and distal edges of olecranon fossa (LOF) and mean values in the right and left directions were respectively $19.10 \pm 1,45$ and $19.46 \pm 1,94 \mathrm{~mm}$. These distances were measured as $20.2 \pm 1.9 \mathrm{~mm}$ in female and $20.3 \pm 1,3 \mathrm{~mm}$ in male by Churchill \& Smith (2000).

Olecranon and coronoid fossa are separated from each other by a thin bone plate. This plate presents till the age of 7 . Later, a foramen, named as septal apertura or supratrochlear foramen is frequently formed in this bone plate. It is emphasized that individuals, who have this anatomical variation, can bring their elbow joint to the extension position. This foramen was defined for the first time by Meckel (1970) and there are important findings which show that this foramen has also been studied in other primates. Recently, intramedullary fixation of the humerus has commonly performed following traumatic injuries and pathological fractures. In line with these data, it is very important to have knowledge related to the anatomical structure of the humerus while planning the preoperative period. In literature, there are various studies in which the prevalence of having supratrochlear foramen is examined in different populations (Table V). Kaur \& Zorasingh (2013), performed a study with 80 dry humerus samples and they showed that a rate of supratrochlear foramen was $27.5 \%$ and according to their 
findings, left humerus were more commonly observed supratrochlear foramens compared to right humerus. This rate was found by Nayak et al., (2009) as 34.3\%, by Erdogmus et al., (2014) as $10.8 \%$ and by Li et al., (2015) as $10.3 \%$. In our study, it was shown that this rate was lower compared to the rate obtained in the study of Kaur \& Zorasingh and it was higher compared to rates obtained from studies performed by Nayak et al., Erdogmus et al., and Li et al. Besides, it was also detected that the supratrochlear foramen commonly had an oval appearance.

AYDIN KABAKCI, A. D.; BUYUKMUMCU, M.; YILMAZ, M. T.; CICEKCIBASI, A. E.; AKıN, D. \& CIHAN, E. Estudio osteométrico del húmero. Int. J. Morphol., 35(1):219-226, 2017.

RESUMEN: El húmero es el hueso más largo y grueso del miembro superior. Como un hueso largo, tiene dos epífisis y una diáfisis. En este estudio, se pretende realizar mediciones morfométricas pertenecientes al húmero humano. Este estudio se realizó en 60 húmeros (28 derechos, 32 izquierdos) en colecciones del Laboratorio de Anatomía de la Facultad de Medicina Meram,Necmettin Erbakan University, Se utilizaron calibradores digitales, tableros osteométricos y escalas de precisión para medir el húmero. Las mediciones se clasificaron como medidas de húmero proximal, corporal y distal. Se determinó el peso de cada hueso. También se determinó el número y la localización de los forámenes nutricios. La longitud media del húmero derecho fue de 30,41 $\pm 1,73 \mathrm{~mm}$ y la del húmero izquierdo fue de 30,04 $\pm 2,39 \mathrm{~mm}$. El peso medio del húmero derecho fue 115,05 $\pm 28,06$ g y el izquierdo 111,63 $\pm 33,34$ g. En 9 húmeros (15\%), se observó un foramen supratroclear, seis de ellos eran ovales y tres redondos.No se observó foramen nutricio en dos húmeros $(3,3 \%)$. Además, se identificó una correlación media y débil entre varios parámetros. Creemos que los datos obtenidos de este estudio pueden ser de referencia para la determinación del sexo de un individio a partir del húmero.

PALABRAS CLAVE: Húmero; Morfometría; Osteometría.

\section{REFERENCES}

Akman, S. D.; Karakas, P. \& Bozkır, M. G. The morphometric measurements of humerus segments. Turk. J. Med. Sci., 36(2):81-5, 2006.

Bokariya, P. Bokariya, R. Gudadhe, D.; Shyamal, A.; Tirpude, B. H. \& Shende, M. R. The anthropometric measurement of humerus segments. J. Forensic Med. Toxicol., 28(1):53-5, 2011.

Churchill, S. E. \& Smith, F. H. A modern human humerus from the early Aurignacian of Vogelherdhöhle (Stetten, Germany). Am. J. Phys. Anthropol., 112(2):251-73, 2000.

Çimen, M.; Kosar, Y. \& Sönmez, M. Humerusta apertura septalis ile ilgili bir arastırma. Antropoloji, 14:20-3, 2003.

Desai, S. D. \& Shaik, H. S. A morphometric study of humerus segments. $J$. Pharm. Sci. Res., 4(10):1943-5, 2012.

Desai, S. J.; Deluce, S.; Johnson, J. A.; Ferreira, L. M.; Leclerc, A. E.; Athwal, G. S. \& King, G. J. An anthropometric study of the distal humerus. J. Shoulder Elbow Surg., 23(4):463-9, 2014.

Diwan, R. K.; Rani, A.; Rani, A.; Chopra, J.; Srivastava, A. K.; Sharma, P. K.; Verma, R. K. \& Pankaj, A. K. Incidence of supratrochlear foramen of humerus in North Indian population. Biomed. Res. (India), 24(1):142$5,2013$.

Erdogmus, S.; Guler, M.; Eroglu, S. \& Duran, N. The importance of the supratrochlear foramen of the humerus in humans: an anatomical study. Med. Sci. Monit., 20:2643-50, 2014.

Harun, K. Kolve Bacak Kemiklerindeki Cinsiyet Kriterleri: Tepecik Toplumu Üzerinde Bir Inceleme. Ph.D. Thesis. Ankara, Ankara University, 2008.,

Kaur, J. \& Zorasingh. Supratrochlear foramen of humerus - A morphometric study. Indian J. Basic Appl. Med. Res., 2(7):651-4, 2013.

Kumarasamy, S. A.; Subramanian, M.; Gnanasundaram, V,; Subramanian, A. \& Ramalingam. Study of intercondyloid foramen of humerus. Rev. Argent. Anat. Clin., 3(1):32-6, 2011.

Latimer, H. B. \& Lowrance, E. W. Bilateral asymmetry in weight and in length of human bones. Anat. Rec., 152(2):217-24, 1965.

Li, J.; Mao, Q.; Li, W. \& Li, X. An anatomical study of the supratrochlear foramen of the Jining population. Turk. J. Med. Sci., 45(6):1369-73, 2015.

Meckel, J. H.; Kate, B. R. \& Dubey, P. N. A note on the septal apertures in the humerus of Central Indians. East. Anthropol., 33:270-84, 1970.

Nayak, S. R.; Das, S.; Krishnamurthy, A.; Prabhu, L. V. \& Potu, B. K. Supratrochlear foramen of the humerus: An anatomico-radiological study with clinical implications. Ups. J. Med. Sci., 114(2):90-4, 2009.
Ndou, R.; Smith, P.; Gemell, R. \& Mohatla, O. The supratrochlear foramen of the humerus in a South African dry bone sample. Clin. Anat., 26(7):870-4, 2013.

Niraj, P.; Dangol, P. M. S. \& Ranjit, N. Measurement of length and weight on non-articulated adult humerus in Nepalese corp ses. J. Kathmandu Med. Coll., 2(1):25-7, 2014.

Öztürk, A. Humerusta foramen supratrochlearis (anatomik çalısma). Ist. Tip. Fak. Mecmuası., 63(1):55-8, 2000.

Patel, S. V.; Sutaria, L. K.; Nayak, T. V.; Kankiya, D. P.; Patel, B. M. \& Aterkar, S. H. Morphomeric study of supratrochlear foramen of humerus. Int. J. Biomed. Adv. Res., 4(2):89-92, 2013.

Salles, A. D.; Carvalho, C. R. F.; Silva, D. M. \& Santana, L. A. Reconstruction of humeral length from measurements of its proximal and distal fragments. Braz. J. Morphol. Sci., 26(2):55-61, 2009.

Singhal, S. \& Rao, V. Supratrochlear foramen of the humerus. Anat. Sci. Int., 82(2):105-7, 2007.

Somesh, M. S.; Prabhu, L. V.; Shilpa, K.; Pa1, M. M.; Krıshnamurthy, A. \& Murlımanju, B. V. Morphometric study of the humerus segments in Indian population. Int. J. Morphol., 29(4):1174-80, 2011.

Sunday, O. O.; Olusegun, O. S. \& Oluwabunmi, B. M. The supratrochlear foramen of the humerus: Implications for intramedullary nailing in distal humerus. J. Biol. Agric. Healthc., 4(7):136-9, 2014.

Tellioglu, A. M. \& Karakas, S. Humerus'tan morfometrik yöntemlerle cinsiyet tayini. F. Ü. Sag. Tip Derg., 27(2):75-9, 2013.

Udhaya, K.; Sarala Devi, K. V. \& Sridhar, J. Regression equation for estimation of length of humerus from its segments: A South Indian population study. J. Clin. Diagn. Res., 5(4):783-6, 2011.

Corresponding author:

Anil Didem

AYDIN KABAKÇI, Instructor

Department of Anatomy

Meram Faculty of Medicine

University of Necmettin Erbakan

42080 Meram, Konya

TURKEY

Received: 07-06-2016

Accepted: 23-11-2016

Email: anil_didem_aydin@hotmail.com 